The author replies below

Dr James has every reason to be confused - the words 'centripetal' (ie towards the centre) and 'centrifugal' (away from the centre) have been transposed! I am grateful to him for drawing my attention to this error. With reference to his second point, I entirely accept that the descriptions by Etienne and Sarpi of the venous valves preceeded Fabricius' own account. However, since neither author made use of mechanical analogy in his description they did not fall within the scope of this particular article.

J R NOVELL Academic Department of Surgery Royal Free Hospital Pond Street, London NW3 2QG

\section{Chronic snorers and sleep apnoea}

The article by D E Golding-Wood and his team (June 1990 JRSM, p 363) on the assessment of chronic snorers and the incidence of sleep apnoea makes one wonder if there is not a relationship between apnoea and the so-called degenerative diseases of the CNS, eg senile dementia and Alzheimer's disease. In the course of clinical practice I came across several patients whose dementia seemed to be closely related to the experience of a dental anaesthetic. In sleep apnoea, when the $\mathrm{PaO}_{2}$ becomes sufficiently low, the patient awakes, sometimes in ventricular arrhythmia. But perhaps by then oxygen lack may have already 'persuaded' a senescent cell complex in the cerebral cortex to become nonfunctional. If sleep apnoea episodes become part of a patient's nocturnal existence cortical damage could become profound. Perhaps the prevention of sleep apnoea should become a matter of some urgency in a population in which nearly $40 \%$ are chronic snorers.

E TRIMMER

Editor, British Journal of Clinical Practice Tower House, Southampton Street, London WC2E 7LS

\section{The death of Mozart}

I was intrigued by the letter to you from Dr Banerjee (June 1990 JRSM, p 414) with regard to Mozart's skull in the Mozarteum.

I had always understood that Mozart had died at an early age and was buried in an unmarked pauper's grave on a grey and rainy day, with not a friendly soul present in attendance. This scene was poignantly recreated in the film Amadeus.

Mozart presumably took his adult skull to the grave with him. I wonder which of Mozart's skulls is in the Mozarteum, the one he had in childhood, that as a youngster, or that as an adolescent?

Is it perhaps as substantial as King Charles' head in Dickens' David Copperfield?

F I JACKSON

Cross Cancer: Institute 11560 University Avenue Edmonton, Alberta, Canada

\section{The death of Schubert}

In a book on Music \& Medicine, reviewed by V C Medvei (July 1990 JRSM, p 480), Dr J O'Shea drew attention to the diagnostic uncertainties of many diseases, including syphilis, in previous centuries, and to indiscriminate treatments with laxatives (herbal and mercurial), repeated bleedings, etc. which often added iatrogenic disorders to the patients' ills.
The tragic death of Franz Schubert (1797-1828) appears to be of particular topical interest. In a recent biography of Schubert, not mentioned in O'Shea's book, Marek ${ }^{1}$ describes his life in Vienna, in a circle of mainly aristocratic bon vivants, some of which had homosexual leanings. This might have been the case of Franz von Schober (1796-1882) a dilettante, who befriended Schubert; and extended to him hospitality in his home (rather the home of his mother; von Schober remained unmarried till he was about 58 years of age). When Schubert stayed with von Schober from 1821 to 1823 , he became seriously ill; syphilis was suspected, and he was treated, inter alia, with large doses of mercurial preparations. The health of Schubert sufficiently improved to allow him to perform in the provinces in the company of another friend, the singer, Johann Michael Vogt.

However, a subsequent spell of von Schober's hospitality resulted in deterioration of Schubert's health. He went to live with his brother, in September 1828, developed abdominal pain, intractable diarrhoea, etc. in October, and died on the 19 November 1828, when only 31 years old. His friend, von Schober, lived to the advanced age of 86 years. Schubert's death has been variously attributed to typhus, typhoid fever, fish poisoning, and others. The rapid course of his stomach disorder, whatever its causes, suggests low immune status.

The recent outbreak of AIDS among the modern gay communities, focused attention on the importance of the immune system, and on its vulnerability to a variety of toxic factors, whether exogenous, or formed endogenously, under specific conditions ${ }^{2,3}$. It is usually the passive partners (the catamites), who are the main sufferers of AIDS. The poor, defenceless Schubert, preoccupied with his musical creation, might possibly have died of AIDS. How to prove, or disprove this hypothesis? $\begin{array}{lr}\text { R SCHOENTAL } & 15 \text { Birdhurst Court } \\ \text { Wallington, Surrey SM6 OPG }\end{array}$

\section{References}

1 Marek GR. Schubert. London: Hale, 1986

2 Schoental R. Immunotoxicology, AIDS, and toxic chemicals. J Appl Toxicol 1988;8:295

3 Schoental R. AIDS, and neoplasias associated with AIDS; immunosuppression by $N$-nitroso compounds endogenously formed from semen. Int $J$ Environ Studies 1988;31:269-78

\section{Diet and large bowel cancer}

I have read Dr Bingham's editorial (July 1990 JRSM, p 420) with great interest. In $1981 \mathrm{~J} L$ Thornton put forward the hypothesis in the Lancet that a high colonic $\mathrm{pH}$ promoted the degradation by colonic bacteria of bile acids and cholesterol into (CO) carcinogens ${ }^{1}$. He also mentioned that a high fibre diet lowered the colonic $\mathrm{pH}$ as a result of bacterial digestion of fibre into short chain fatty diets.

In 1982 I reported a lower faecal $\mathrm{pH}$ in a population of railway workers in North India than in a similar group from South India 2 . The North Indian diet of unrefined wheat, pulses and other legumes has a high fibre content and is accompanied by a higher intake of short chain fatty acids in the form of yoghurt, white cheese and ghee.

The South Indian diet of rice, tapioca, ragi and tamarind powder is low in fibre and also low in milk and fermented milk products. 
Table 1. Mean faecal pH values $( \pm S D)$

\begin{tabular}{|c|c|}
\hline $\begin{array}{l}\text { Colorectal cancer } \\
60 \text { patients }\end{array}$ & $8.6 \pm 1.68^{*}$ \\
\hline Controls & \\
\hline 60 railway employees & $\begin{array}{l}7.0 \pm 1.57 \\
6.5+1.56\end{array}$ \\
\hline
\end{tabular}

${ }^{*} P<0.001$ compared with each group of controls

Table 2. Distribution of faecal $\mathrm{pH}$ values

$p H$

$5.0-6.1-6.6-7.1-7.6-8.1-8.6-9.1-9.6-$ $\begin{array}{lllllllll}6.0 & 6.5 & 7.0 & 7.5 & 8.0 & 8.5 & 9.0 & 9.6 & 10.0\end{array}$

\begin{tabular}{|c|c|c|c|c|c|c|c|c|c|}
\hline \multicolumn{10}{|c|}{ Colorectal cancer } \\
\hline 60 patients & 0 & 0 & 4 & 6 & 6 & 7 & 24 & 10 & 3 \\
\hline \multicolumn{10}{|l|}{ Controls } \\
\hline $\begin{array}{l}60 \text { railway } \\
\text { employees }\end{array}$ & 10 & 8 & 18 & 7 & 3 & 5 & 7 & 2 & 0 \\
\hline $\begin{array}{l}60 \text { from } \\
\text { general } \\
\text { population }\end{array}$ & 18 & 12 & 7 & 8 & 6 & 5 & 2 & 2 & $\mathbf{0}$ \\
\hline
\end{tabular}

$\chi^{2}$ test: cancer patients $\mathrm{v}$ controls (grouped)

(test for independence applied by group intervals to obtain theoretical frequencies of not less than five) $\chi^{2}=29.88, P<0.001$

The incidence of colorectal cancer is higher in South Indians than in North Indians ${ }^{3,4}$ which would support the hypothesis propounded by Thornton in relation to colonic $\mathrm{pH}$. I have done a further study of faecal pH comparing 60 patients with colorectal cancer from the Cancer Registry of the South-eastern Railway Calcutta with 60 matched controls from railway employees and 60 matched controls from the general population. Twenty-four hour faecal samples were collected and pH measurements were made after thorough mixing.

The mean pH measurements are shown in Table 1. To avoid the problems associated with mean values of logarithmic measurements the distribution of the different $\mathrm{pH}$ ranges is shown in Table 2.

It will be seen that the $\mathrm{pH}$ value of the faeces was significantly higher in the colorectal cancer patients than in both groups of controls.

An alkaline milieu renders mucus more fluid, and in that state it escapes more easily from the cell ${ }^{5}$. Loss of mucus from cells is reported to result in hyperplasia, metaplasia, cell atypia and a 40 -fold increase in mitotic activity ${ }^{6,7}$.

There is supporting evidence that a high $\mathrm{pH}$ may be a prelude to cancer in other situations. Exposure to calcium hydroxide results in carcinoma in situ changes in the cheek pouches and oesophagus of hamsters ${ }^{8,9}$ and carcinoma of the mouth is associated with the chewing of pan-containing lime in India. The increased risk of carcinoma of the colon after cholecystectomy ${ }^{10,11}$ may be due to the increased alkalinity of the bile resulting from failure of the absorption of bicarbonate which normally takes place in the gall bladder.

In conclusion, the finding of higher $\mathrm{pH}$ values in patients with colorectal cancer and the fact that these can be affected by diet adds increasing weight to the importance of diet in the aetiology of this condition. S L MALHOTRA
References

1 Thornton JR. High colonic pH promotes colorectal cancer. Lancet 1981;i:1081-3

2 Malhotra SL. Faecal urobilinogen levels and pH of stools in population groups with different incidence of cancer of the colon and their possible role in its aetiology. $J R$ Soc Med 1982;75:709-14

3 Paymaster JC. Cancer and its distribution in India. Cancer 1964;17:1026-34

4 Malhotra SL. Geographical distribution of gastrointestinal cancers in India with special reference to causation. Gut 1967;8:361-72

5 James AH. The physiology of gastric digestion London: Arnold, 1957

6 Lawson HH. Effect of duodenal contents on gastric mucosa under experimental conditions. Lancet 1964; i:469-72

7 du Plessis DJ. Pathogenesis of gastric ulceration. Lancet 1965;i:974-8

8 Dunham LJ, Muir CS, Hamner III JE. Epithelial atypia in hamster cheek pouches treated repeatedly with calcium hydroxide. $\mathrm{Br} J$ Cancer 1966;20:588-93

9 Dunham LJ, Sheets RM, Morton JF. Proliferative lesions in cheek pouches and oesophagus of hamsters treated with plants from Curaco, Netherlands, Antilles. $J$ Natl Cancer Inst 1974;53:1259-69

10 Linos DA, Beard CM, O'Fallon WM, Dockerty MB, Dockerty MB, Beast RW Jr, Kurland LT. Cholecystectomy and right sided colon cancer. Lancet 1981; ii:379-81

11 Vernick LJ, Kuller LH. Cholecystectomy and right sided colon cancer. Lancet 1981;ii:381-3

\section{Spontaneous rupture of renal artery aneurysm}

We read with interest the recent case report by Cheng et al. (July $1990 \mathrm{JRSM}, \mathrm{p} 464$ ) of spontaneous rupture of a renal artery aneurysm but would like to raise some additional points about this increasingly diagnosed condition.

Firstly, we would disagree with their statement that renal artery aneurysm alone is seldom associated with hypertension. The association of proven renovascular hypertension and renal artery aneurysm without renal artery stenosis is well recorded in the literature and such cases stand a good chance of becoming normotensive after surgical correction of the aneurysm ${ }^{1}$. The cause of this associated hypertension is not clear but kinking of the artery, distal embolization or haemodynamic effects due to interference with pulsatility have been suggested as possible reasons ${ }^{2}$. We have recently treated a case of solitary renal artery aneurysm, without associated stenosis, in which the changes produced on Captopril-renography were identical to those of classical renal artery stenosis ${ }^{3}$ and many authors have shown abnormal renal vein renin levels in these patients. The key is the correct diagnosis of the renovascular nature of the hypertension preoperatively as associated hypertension from other causes can not be expected to improve. In the case described, the authors did not report the presence of any stenotic lesion, but also unfortunately failed to tell us whether the patient was hypertensive or normotensive before nephrectomy was performed.

The indications for surgery in renal artery aneurysm remain controversial. Follow-up and post mortem studies have failed to document a significant risk of rupture in most renal artery aneurysms ${ }^{4}$. However, there are many reported cases of rupture in pregnant women and the literature would suggest that 